\title{
Murinocardiopsis flavida gen. nov., sp. nov., an actinomycete isolated from indoor walls
}

Correspondence

P. Kämpfer

peter.kaempfer@umwelt.unigiessen.de

\section{P. Kämpfer, ${ }^{1}$ J. Schäfer, ${ }^{1}$ N. Lodders ${ }^{1}$ and K. Martin ${ }^{2}$}

\author{
${ }^{1}$ Institut für Angewandte Mikrobiologie, Justus-Liebig-Universität Giessen, D-35392 Giessen, \\ Germany \\ ${ }^{2}$ Leibniz-Institut für Naturstoff-Forschung und Infektionsbiologie eV, Hans-Knöll-Institut für \\ Naturstoff-Forschung eV, D-07745 Jena, Germany
}

The family Nocardiopsaceae currently contains five genera, Nocardiopsis (Meyer, 1976), Thermobifida (Zhang et al., 1998), Streptomonospora (Cui et al., 2001), Haloactinospora (Tang et al., 2008) and Marinactinospora (Tian et al., 2009). With more than 25 species and subspecies, the genus Nocardiopsis is the largest genus of the family Nocardiopsaceae. Among the members of this genus are Nocardiopsis dassonvillei subsp. dassonvillei (Meyer, 1976), N. dassonvillei subsp. albirubida (Evtushenko et al., 2000), N. alba, N. listeri (Grund \& Kroppenstedt, 1990), N. halophila (Al-Tai \& Ruan, 1994), N. lucentensis (Yassin et al., 1993), N. prasina, N. synnemataformans (Yassin et al., 1997), N. kunsanensis (Chun et al., 2000), N. tropica, N. trehalosi, N. exhalans, N. umidischolae (Peltola et al., 2001), $N$. halotolerans (Al-Zarban et al., 2002), N. composta (Kämpfer et al., 2002), N. metallicus (Schippers et al., 2002), N. xinjiangensis (Li et al., 2003a), N. alkaliphila

The GenBank/EMBL/DDBJ accession numbers for the 16S rRNA gene sequences of strains $14-\mathrm{Be}-013^{\top}$ and $02-\mathrm{Gi}-014$ are FN393755 and FN393756.

A detailed phenotypic comparison with related type strains is available as supplementary material with the online version of this paper.
(Hozzein et al., 2004), N. salina (Li et al., 2004), N. aegyptia (Sabry et al., 2004), N. baichengensis, N. chromatogenes, N. gilva, N. rhodophaea, N. rosea (Li et al., 2006), N. quinghaiensis (Chen et al., 2008), N. valliformis (Yang et al., 2008a). N. ganjiahuensis (Zhang et al., 2008), N. litoralis (Chen et al., 2009) and N. potens (Yassin et al., 2009). The genus Thermobifida contains four species, namely Thermobifida alba, T. fusca (Zhang et al., 1998), T. cellulosilytica (Kukolya et al., 2002) and T. halotolerans (Yang et al., 2008b). Streptomonospora contains the three species Streptomonospora salina (Cui et al., 2001), S. alba (Li et al., 2003b) and S. halophila (Cai et al., 2008). Haloactinospora and Marinactinospora both contain only one species, Haloactinospora alba (Tang et al., 2008) and Marinactinospora thermotolerans (Tian et al., 2009), respectively.

Many strains of the family Nocardiopsis have been isolated from saline soils, and many of them are halophilic microorganisms, some of them being strictly halophilic (Tang et al., 2008).

In this study, two strains, $14-\mathrm{Be}-013^{\mathrm{T}}$ and $02-\mathrm{Gi}-014$, were isolated from two different sources, both interior house 
walls, heavily colonized with moulds. Primary isolation material for strain $14-\mathrm{Be}-013^{\mathrm{T}}$ was contaminated wallpaper of an outer wall; strain 02-Gi-014 was isolated from mineral wool used as an insulating material for a house wall and heavily colonized with moulds.

After extraction of $1 \mathrm{~g}$ sample material by shaking for $15 \mathrm{~min}$ in $10 \mathrm{ml} 0.9 \% \mathrm{NaCl}$ solution containing $0.01 \%$ $(\mathrm{v} / \mathrm{v})$ Tween 80 , aliquots of this suspension were spread on agar plates containing mineral agar (Gauze et al., 1983; containing $20 \mathrm{~g}$ soluble starch, $1 \mathrm{~g} \mathrm{KNO}_{3}, 0.5 \mathrm{~g} \mathrm{~K}_{2} \mathrm{HPO}_{4}$, $0.5 \mathrm{~g} \mathrm{MgSO}_{4} .7 \mathrm{H}_{2} \mathrm{O}, 0.5 \mathrm{~g} \mathrm{NaCl}, 0.01 \mathrm{~g} \mathrm{FeSO}_{4} \cdot 7 \mathrm{H}_{2} \mathrm{O}$ and $20 \mathrm{~g}_{\text {agar }} \mathrm{l}^{-1}$ ). The agar plates were incubated for 2 weeks at $28{ }^{\circ} \mathrm{C}$. The isolated strains were maintained on organic medium 79 (Prauser \& Falta, 1968) and preserved at $-80{ }^{\circ} \mathrm{C}$ as a $1: 1$ mixture of well-grown cultures in organic medium 79 broth and glycerol preservation medium (Chakrabarty \& Brown, 1978).

Morphological properties, Gram staining and cell morphology were observed microscopically as described by Kämpfer \& Kroppenstedt (2004). Both strains formed yellowish-coloured substrate mycelium on organic medium 79 and beige-coloured substrate mycelium on oatmeal agar. In contrast to many species of the family Nocardiopsaceae, strains $14-\mathrm{Be}-013^{\mathrm{T}}$ and $02-\mathrm{Gi}-014$ did not form aerial mycelium at $28{ }^{\circ} \mathrm{C}$ on the following media: yeast extract-malt extract agar, oatmeal agar [ISP (International Streptomyces Project) medium 2 and ISP medium 3; Shirling \& Gottlieb, 1966], GYM agar (DSM medium 65; http://www.dsmz.de/microorganisms/media list.php), Bennett's agar with sucrose (Jones, 1949) and organic medium 79. Strains $14-\mathrm{Be}-013^{\mathrm{T}}$ and $02-\mathrm{Gi}-014 \mathrm{did}$ not form aerial mycelium on HT medium or on media containing up to $10 \% \mathrm{NaCl}$ after 28 days of incubation. No pigments were released into the medium. Myceliumlike filaments about $1.3 \mu \mathrm{m}$ wide were detected microscopically. The strains stained Gram-positive, were oxidase-positive (weak reaction) and showed an aerobic respiratory metabolism.

Isolation of DNA was performed with a commercial DNA extraction kit (GenElute Plant genomic DNA kit; Sigma) after disruption of cells by a 1 min bead-beating step with $1 \mathrm{~g} 0.1 \mathrm{~mm}$-diameter Zirconia beads at maximum speed. The 16S rRNA gene was analysed as described previously (Kämpfer et al., 2003). Multiple sequence alignment and analysis of the data were performed using the software package MEGA version 4 (Tamura et al., 2007) as well as with the ARB software package (December 2007 version; Ludwig et al., 2004) and the corresponding SILVA SSURef 95 database (July 2008 release; Pruesse et al., 2007). Genetic distances were calculated (distance options according to the Kimura-2 model) and clustering was performed with the neighbour-joining method and maximum-parsimony method (results not shown) using MEGA 4 and bootstrap values based on 1000 replications. Tree reconstruction using the maximum-likelihood method with fastDNAml (Olsen et al., 1994) and a $30 \%$ conservation filter (only alignment columns in which the frequency of the most abundant nucleotide is $\geqslant 30 \%$ were included in the analysis) was performed with the ARB software package (Fig. 1). Tree topology was also tested without filters. No differences could be detected between these trees.

The 16S rRNA gene sequence of strain $14-\mathrm{Be}-013^{\mathrm{T}}$ was a continuous stretch of $1418 \mathrm{bp}$ and that of strain $02-\mathrm{Gi}-014$ was $1452 \mathrm{bp}$. Sequence similarity calculations indicated that the closest relatives of strains $14-\mathrm{Be}-013^{\mathrm{T}}$ and $02-\mathrm{Gi}-$ 014 were the type strains of Marinactinospora thermotolerans $\left(96.0 \%\right.$ similarity to $14-\mathrm{Be}-013^{\mathrm{T}} ; 95.1 \%$ to $\left.02-\mathrm{Gi}-014\right)$, $N$. dassonvillei subsp. albirubida and $N$. lucentensis ( $95.3 \%$ to $14-\mathrm{Be}-013^{\mathrm{T}}$; 95.4 and $95.2 \%$, respectively, to $02-\mathrm{Gi}-014)$ and N. alba and N. listeri $\left(95.2 \%\right.$ to $14-\mathrm{Be}-013^{\mathrm{T}}$ and 02-Gi-014).

Bacterial biomass for chemotaxonomic investigations of the isolates was prepared by cultivating the strains for 24$48 \mathrm{~h}$ in shake flasks in liquid organic medium M79 at 180 r.p.m. at $28{ }^{\circ} \mathrm{C}$ except for fatty acid analyses, for which cells were grown on tryptic soy agar.

The cell-wall amino acids were determined by TLC according to Schleifer \& Kandler (1972) and whole-cell sugars by TLC as described by Becker et al. (1965). The occurrence of mycolic acids was determined by TLC as described by Minnikin et al. (1975). Menaquinones were extracted and analysed as described by Collins et al. (1979) and Groth et al. (1996). Polar lipids extracted by the method of Minnikin et al. (1979) were identified by twodimensional TLC as described by Collins \& Jones (1980). Fatty acid analysis was performed according to Kämpfer \& Kroppenstedt (1996).

Whole-organism hydrolysates of strains $14-\mathrm{Be}-013^{\mathrm{T}}$ and 02-Gi-014 contained meso-diaminopimelic acid as the diagnostic diamino acid of the peptidoglycan, which is typical of members of the family Nocardiopsaceae (wall chemotype III sensu Lechevalier \& Lechevalier, 1970), and glucose, typical of members of the genera Nocardiopsis and Thermobifida (in combination with galactose and xylose), but not of members of the genera Streptomonospora, Haloactinospora and Marinactinospora. Mycolic acids were absent. The menaquinone profiles of the strains were slightly different in the ratio of the predominant menaquinones: strain $14-\mathrm{Be}-013^{\mathrm{T}}$ contained $\mathrm{MK}-10\left(\mathrm{H}_{4}\right)$, MK$11\left(\mathrm{H}_{4}\right)$, MK-12( $\left.\mathrm{H}_{2}\right)$, MK-10 $\left(\mathrm{H}_{8}\right)$ and MK-10 $\left(\mathrm{H}_{6}\right)$ in a ratio of $33: 27: 12: 10: 5$, whereas strain $02-\mathrm{Gi}-014$ contained MK-10 $\left(\mathrm{H}_{4}\right)$, MK-11 $\left(\mathrm{H}_{4}\right), \mathrm{MK}-12\left(\mathrm{H}_{2}\right), \mathrm{MK}-10\left(\mathrm{H}_{8}\right)$ and MK-9 $\left(\mathrm{H}_{4}\right)$ in a ratio of $17: 18: 25: 14: 5$.

The phospholipids (Fig. 2) were composed of the diagnostic lipids phosphatidylcholine, phosphatidylinositol, diphosphatidylglycerol, phosphatidylglycerol and four unknown lipids. Phosphatidylmethylethanolamine, found in most Nocardiopsis and Thermobifida species but not in Streptomonospora, Haloactinospora or Marinactinospora species, was not detected. Both strains contained one unknown phospholipid with a high $R_{\mathrm{f}}$ value above that for 


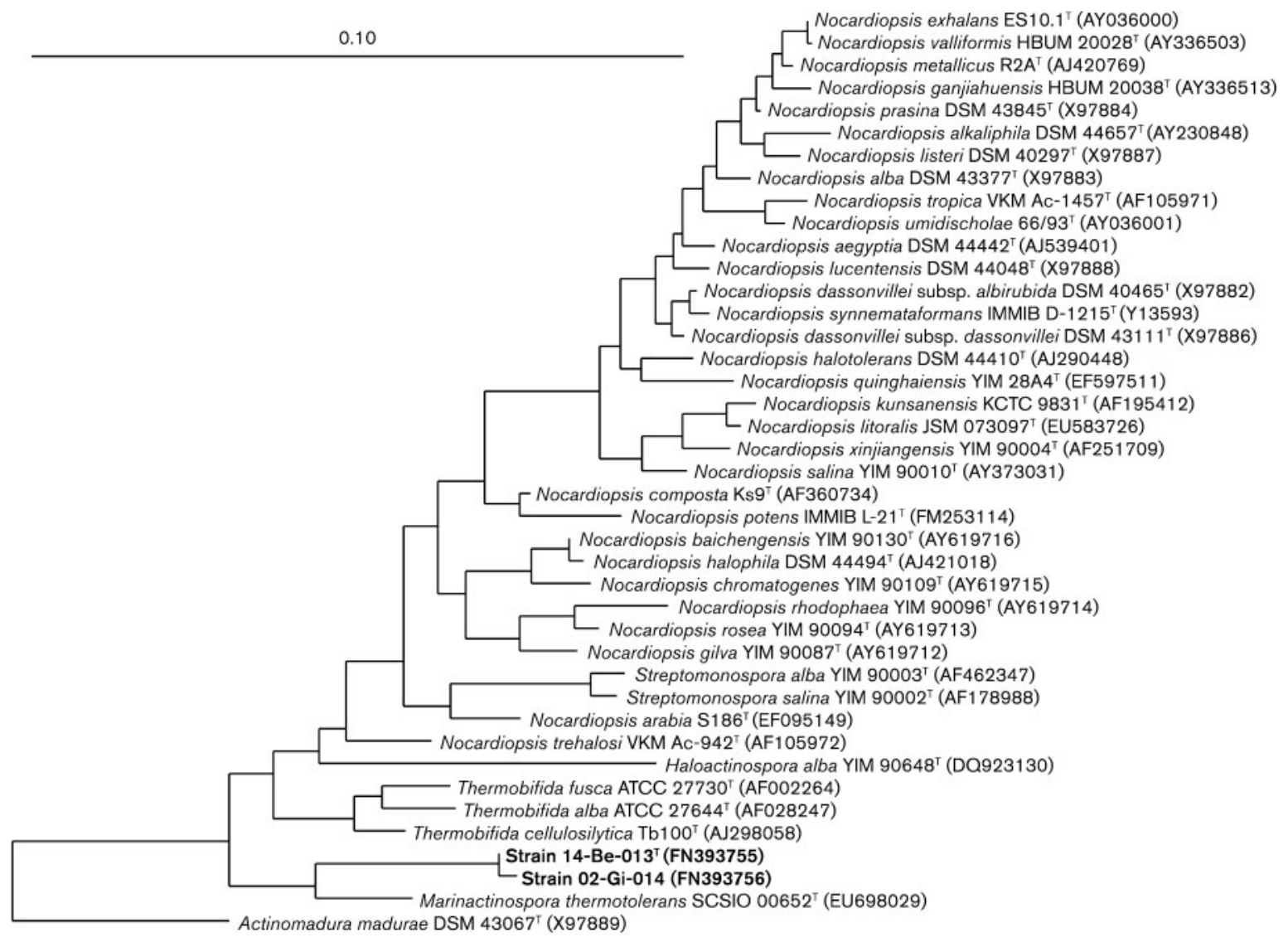

Fig. 1. Phylogenetic analysis based on $16 \mathrm{~S}$ rRNA gene sequences available from the EMBL database (accession numbers in parentheses). The tree was constructed using the ARB software package (December 2007 version; Ludwig et al., 2004) and the corresponding SILVA SSURef 95 database (July 2008 release; Pruesse et al., 2007). Tree building was performed using the maximum-likelihood method with fastDNAml (Olsen et al., 1994) and with a $30 \%$ conservation filter. For better clarity, only a subset of the sequences used for treeing is shown. Bar, 0.10 substitutions per nucleotide position.

diphosphatidylglycerol and one unknown phospholipid with an $R_{\mathrm{f}}$ value similar to that of phosphatidylcholine. In addition, strain $14-\mathrm{Be}-013^{\mathrm{T}}$ contained two unknown phospholipids with similar $R_{\mathrm{f}}$ values to that of phosphatidylinositol, whereas strain 02-Gi-014 contained two glycolipids. The occurrence of phosphatidylcholine and phospholipids with higher $R_{\mathrm{f}}$ values than diphosphatidylglycerol was described as a typical characteristic for members of the genus Nocardiopsis by Peltola et al. (2001) and Al-Zarban et al. (2002). In Table 1, the
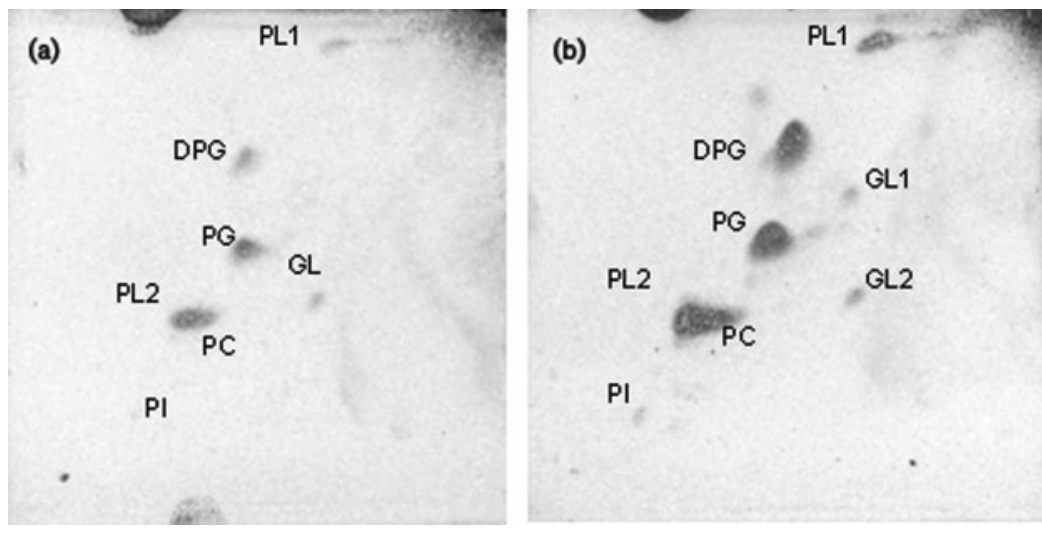

Fig. 2. Two-dimensional TLC of polar lipid extracts from strains $14-\mathrm{Be}-013^{\top}$ (a) and 02Gi-014 (b), stained with molybdatophosphoric acid. DPG, Diphosphatidylglycerol; PC, phosphatidylcholine; PG, phosphatidylglycerol; $\mathrm{PI}$, phosphatidylinositol; GL, unknown glycolipid; $\mathrm{PL}$, unknown phospholipid. 
Table 1. Chemotaxonomic characteristics of strain $14-\mathrm{Be}-013^{\top}$ and related genera of the family Nocardiopsaceae

Taxa: 1, 14-Be-013 ${ }^{\mathrm{T}}$; 2, Marinactinospora (data from Tian et al., 2009) 3, Nocardiopsis (Kroppenstedt \& Evtushenko, 2006); 4, Thermobifida (Yang et al., 2008b); 5, Streptomonospora (Cai et al., 2008); 6, Haloactinospora (Tang et al., 2008). Important diagnostic carbohydrates like arabinose, galactose, xylose, madurose (cell-wall types according to Lechevalier, 1968) and rhamnose for differentiation from the genus Saccharothrix (Grund \& Kroppenstedt, 1990) were not detected in the novel strains.

\begin{tabular}{|c|c|c|c|c|c|c|}
\hline Characteristic & 1 & 2 & 3 & 4 & 5 & 6 \\
\hline $\begin{array}{l}\text { Major } \\
\text { menaquinones }\end{array}$ & $\begin{array}{r}10\left(\mathrm{H}_{4}\right), 11\left(\mathrm{H}_{4}\right), \\
12\left(\mathrm{H}_{2}\right), 10\left(\mathrm{H}_{8}\right)\end{array}$ & $\begin{array}{l}10\left(\mathrm{H}_{8}\right), 11\left(\mathrm{H}_{8}\right), \\
11\left(\mathrm{H}_{10}\right),\end{array}$ & $\begin{array}{l}10\left(\mathrm{H}_{2}\right), 10\left(\mathrm{H}_{4}\right), \\
10\left(\mathrm{H}_{6}\right), 9\left(\mathrm{H}_{4}\right), \\
9\left(\mathrm{H}_{6}\right)\end{array}$ & $\begin{array}{l}10\left(\mathrm{H}_{4}\right), 10\left(\mathrm{H}_{6}\right) \\
10\left(\mathrm{H}_{8}\right), 11\left(\mathrm{H}_{6}\right) \\
11\left(\mathrm{H}_{8}\right)\end{array}$ & $\begin{array}{r}10\left(\mathrm{H}_{4}\right), 10\left(\mathrm{H}_{6}\right) \\
10\left(\mathrm{H}_{8}\right), 11\left(\mathrm{H}_{8}\right)\end{array}$ & $\begin{array}{r}10\left(\mathrm{H}_{8}\right), 11\left(\mathrm{H}_{4}\right), \\
11\left(\mathrm{H}_{6}\right), 11\left(\mathrm{H}_{8}\right)\end{array}$ \\
\hline Polar lipids* & $\begin{array}{l}\text { PC, PG, PI, DPG, } \\
\text { PL1, PL2, GL }\end{array}$ & $\begin{array}{l}\text { PC, DPG, PG, } \\
\text { PIM, PI, PL }\end{array}$ & PC, PME & $\begin{array}{c}\text { DPG, PME, PC, } \\
\text { PI, PG, PE, PL }\end{array}$ & $\begin{array}{l}\text { DPG, PG, PC, } \\
\text { PIM, PI, PE, } \\
\text { MPE, PS, PL }\end{array}$ & $\begin{array}{r}\text { DPG, PG, } \\
\text { PC, PIM }\end{array}$ \\
\hline $\begin{array}{l}\text { Major fatty } \\
\text { acids }(>10 \%) \dagger\end{array}$ & $\begin{array}{l}\mathrm{i}-\mathrm{C}_{16: 0}, \text { ai }-\mathrm{C}_{17: 0} \\
\mathrm{C}_{18: 1} \omega 9 c\end{array}$ & $\begin{array}{l}\mathrm{i}-\mathrm{C}_{16: 0}, \mathrm{i}-\mathrm{C}_{16: 1} \\
\quad \mathrm{G}, 10-\mathrm{Me} \mathrm{C}_{18: 1}\end{array}$ & $\begin{array}{c}\mathrm{i}-\mathrm{C}_{16: 0}, \text { ai- } \mathrm{C}_{17: 0} \\
10-\mathrm{Me} \mathrm{C}_{18: 1}\end{array}$ & $\begin{array}{l}\mathrm{i}-\mathrm{C}_{16: 0} \\
\text { ai- } \mathrm{C}_{17: 0}\end{array}$ & $\begin{array}{c}\mathrm{i}-\mathrm{C}_{15: 0}, \mathrm{i}-\mathrm{C}_{16: 0} \\
\text { ai- } \mathrm{C}_{17: 0}, 9-\mathrm{Me} \\
\mathrm{C}_{16: 0}, 10-\mathrm{Me} \\
\mathrm{C}_{17: 0}, 10-\mathrm{Me} \mathrm{C}_{1}\end{array}$ & $\begin{array}{l}\mathrm{i}-\mathrm{C}_{16: 0} \\
\text { ai- } \mathrm{C}_{17: 0}\end{array}$ \\
\hline
\end{tabular}

${ }^{\star}$ DPG, Diphosphatidylglycerol; MPE, methylphosphatidylethanolamine; PC, phosphatidylcholine; PE, phosphatidylethanolamine; PG, phosphatidylglycerol; PI, phosphatidylinositol; PIM, phosphatidylinositol mannosides; PL, unknown phospholipids; PME, phosphatidylmethylethanolamine; PS, phosphatidylserine; GL, glycolipid.

†ai, Anteiso-branched; i, iso-branched; Me, methyl.

chemotaxonomic characteristics that differentiate strains $14-\mathrm{Be}-013^{\mathrm{T}}$ and $02-\mathrm{Gi}-014$ from the most closely related members of the family Nocardiopsaceae are summarized.

The fatty acid profile of strain $14-\mathrm{Be}-013^{\mathrm{T}}$ was composed of the major fatty acids iso- $\mathrm{C}_{16: 0}(24.4 \%)$, anteiso- $\mathrm{C}_{17: 0}$ $(18.0 \%)$ and $\mathrm{C}_{18: 1} \omega 9 c(24.5 \%)$. Minor amounts of iso$\mathrm{C}_{14: 0}(1.4 \%)$, anteiso- $\mathrm{C}_{15: 0}(6.2 \%), \mathrm{C}_{16: 1} \omega 6 c(2.5 \%)$, $\mathrm{C}_{16: 0}(4.3 \%)$, iso- $\mathrm{C}_{17: 0}(1.0 \%), \mathrm{C}_{17: 1} \omega 8 c(5.3 \%), \mathrm{C}_{17: 0}$ (0.9\%), 10-methyl $\mathrm{C}_{17: 0}(1.6 \%)$, iso- $\mathrm{C}_{18: 0}(1.0 \%), \mathrm{C}_{18: 0}$ (3.5\%) and 10-methyl $\mathrm{C}_{18: 0}(3.8 \%)$ were also detected. The fatty acid profile of strain $02-\mathrm{Gi}-014$ was composed of iso- $\mathrm{C}_{16: 0}(30.5 \%)$, anteiso- $\mathrm{C}_{17: 0}(10.4 \%)$ and $\mathrm{C}_{18: 1} \omega 9 c$ $(13.0 \%)$, with minor amounts of iso- $\mathrm{C}_{14: 0}(4.5 \%)$, anteiso- $\mathrm{C}_{15: 0}(6.2 \%), \mathrm{C}_{16: 1} \omega 6 c(3.0 \%), \mathrm{C}_{16: 0}(8.0 \%)$, $\mathrm{C}_{17: 1} \omega 8 c(1.6 \%)$, 10-methyl $\mathrm{C}_{17: 0}(1.6 \%)$, iso- $\mathrm{C}_{18: 0}$ $(0.8 \%), \mathrm{C}_{18: 0}(4.1 \%)$ and 10-methyl $\mathrm{C}_{18: 0}(9.0 \%)$. This fatty acid profile is in accordance with those published for Nocardiopsis species and is most similar to that of Marinactinospora thermotolerans.

Results of comparative physiological characterization, using identical test conditions, are given in Supplementary Table S1 (available in IJSEM Online) and in the species description, with methods described previously (Kämpfer et al., 1991). Several test results were obtained that enable the differentiation of strains $14-\mathrm{Be}-013^{\mathrm{T}}$ and 02-Gi-014 from the most closely related Nocardiopsis and Marinactinospora species. We did not perform DNA-DNA hybridizations because of the low $16 \mathrm{~S}$ rRNA gene sequence similarities $(<97 \%)$ to all other type strains of the family Nocardiopsaceae.

From the results of the 16S rRNA gene sequencing as well as the observed genotypic, phenotypic and chemotaxonomic differences (Table 1 and Supplementary Table S1), it is evident that strains $14-\mathrm{Be}-013^{\mathrm{T}}$ and $02-\mathrm{Gi}-014$ form a distinct phylogenetic lineage within the family Nocardiopsaceae. Therefore, a novel genus with the name Murinocardiopsis gen. nov. is proposed, which contains one species, Murinocardiopsis flavida sp. nov.

\section{Description of Murinocardiopsis gen. nov.}

Murinocardiopsis (Mu.ri.no.car'di.op'sis. L. n. murus wall; N.L. fem. n. Nocardiopsis a bacterial genus name; N.L. fem. n. Murinocardiopsis a Nocardiopsis-like organism isolated from a wall).

Gram-stain-positive and oxidase-positive (weak reaction), showing an aerobic respiratory metabolism. Form mycelium-like filaments, about $1.3 \mu \mathrm{m}$ wide. No aerial mycelium is formed. The diagnostic diamino acid of the peptidoglycan is meso-diaminopimelic acid. Mycolic acids are absent. The major menaquinones are MK-10 $\left(\mathrm{H}_{4}\right)$, MK$11\left(\mathrm{H}_{4}\right)$, MK-12( $\left.\mathrm{H}_{2}\right)$ and MK-10 $\left(\mathrm{H}_{8}\right)$. The polar lipid profile consists of phosphatidylcholine, diphosphatidylglycerol, phosphatidylglycerol, phosphatidylinositol and unknown lipids, including one unknown phospholipid with a higher $R_{\mathrm{f}}$ than diphosphatidylglycerol. Major fatty acids are iso- $\mathrm{C}_{16: 0}$, anteiso- $\mathrm{C}_{17: 0}$ and $\mathrm{C}_{18: 1} \omega 9 c$. The type species is Murinocardiopsis flavida.

\section{Description of Murinocardiopsis flavida sp. nov.}

Murinocardiopsis flavida (fla'vi.da. L. fem. adj. flavida yellowish).

Displays the same morphological, chemotaxonomic and general characteristics as described for the genus. Substrate 
mycelium on M79 agar is yellowish. Minor fatty acids include iso- $\mathrm{C}_{14: 0}$, anteiso- $\mathrm{C}_{15: 0}, \mathrm{C}_{16: 1} \omega 6 c, \mathrm{C}_{16: 0}$, iso$\mathrm{C}_{17: 0}, \mathrm{C}_{17: 1} \omega 8 c, \mathrm{C}_{17: 0}, 10$-methyl $\mathrm{C}_{17: 0}$, iso- $\mathrm{C}_{18: 0}, \mathrm{C}_{18: 0}$ and 10-methyl $\mathrm{C}_{18: 0}$. N-Acetyl-D-glucosamine, L-arabinose, arbutin, cellobiose, D-fructose, D-glucose, D-galactose, maltose, L-rhamnose, salicin, trehalose, D-xylose, D-adonitol, myo-inositol, D-mannitol, D-mannose, ribose, acetate (weak), fumarate (weak), DL-lactate, L-malate, 3hydroxy-DL-butyrate, pyruvate and L-proline are utilized as sole sources of carbon. Melibiose, gluconate, maltitol, Dsorbitol, sucrose, putrescine, propionate, 4-aminobutyrate, citrate, trans-aconitate, itaconate, 2-oxoglutarate and mesaconate are not utilized as sole carbon sources.

The type strain, $14-\mathrm{Be}-013^{\mathrm{T}}\left(=\mathrm{DSM} \quad 45312^{\mathrm{T}}=\mathrm{CCM}\right.$ $7612^{\mathrm{T}}$ ), was isolated in Berlin, Germany, by $\mathrm{Dr} \mathrm{C}$. Trautmann, sampled from wallpaper of an outer house wall and colonized with moulds. A second strain of the species, strain 02-Gi-014, was isolated in Giessen, by one of us (J.S.), from mineral wool used as an insulating material for a house wall and heavily colonized with moulds.

\section{Acknowledgements}

We are grateful to Carmen Schult and Gundula Will for excellent technical assistance and Jean Euzéby for support with the nomenclature. The study was supported in part by the Federal Environment Agency (Umweltbundesamt), grant number FKZ 20562236.

\section{References}

Al-Tai, A. M. \& Ruan, J. S. (1994). Nocardiopsis halophila sp. nov., a new halophilic actinomycete isolated from soil. Int J Syst Bacteriol 44, 474-478.

Al-Zarban, S. S., Abbas, I., Al-Musallam, A. A., Steiner, U., Stackebrandt, E. \& Kroppenstedt, R. M. (2002). Nocardiopsis halotolerans sp. nov., isolated from salt marsh soil in Kuwait. Int $J$ Syst Evol Microbiol 52, 525-529.

Becker, B., Lechevalier, M. P. \& Lechevalier, H. A. (1965), Chemical composition of cell-wall preparations from strains of various form-genera of aerobic actinomycetes. Appl Microbiol 13, 236-243.

Cai, M., Zhi, X.-Y., Tang, S.-K., Zhang, Y.-O., Xu, L.-H. \& Li, W.-J. (2008). Streptomonospora halophila sp. nov., a halophilic actinomycete isolated from a hypersaline soil. Int J Syst Evol Microbiol 58, 1556-1560.

Chakrabarty, A. M. \& Brown, J. F. (1978). Microbial genetic engineering by natural plasmid transfer. In Genetic Engineering, pp. 185-193. Edited by A. M. Chakrabarty. West Palm Beach, FL: CRC Press.

Chen, Y.-G., Cui, X.-L., Kroppenstedt, R. M., Stackebrandt, E., Wen, M.-L., Yu, L.-H. \& Jiang, C.-L. (2008). Nocardiopsis quinghaiensis sp. nov., isolated from saline soil in China. Int J Syst Evol Microbiol 58, 699-705.

Chen, Y.-G., Wang, Y.-X., Zhang, Y.-Q., Tang, S.-K., Liu, Z.-X., Xiao, H.-D., Xu, L.-H., Cui, X.-L. \& Li, W.-X. (2009). Nocardiopsis litoralis sp. nov., a halophilic marine actinomycete isolated from a sea anemone. Int J Syst Evol Microbiol 59, 2708-2713.

Chun, J., Bae, K. S., Moon, E. Y., Jung, S.-O., Lee, H. K. \& Kim, S.-J. (2000). Nocardiopsis kunsanensis sp. nov., a moderately halophilic actinomycete isolated from a saltern. Int J Syst Evol Microbiol 50, 1909-1913.

Collins, M. D. \& Jones, D. (1980). Lipids in the classification and identification of coryneform bacteria containing peptidoglycans based on 2,4-diaminobutyric acid. J Appl Bacteriol 48, 459-470.

Collins, M. D., Goodfellow, M. \& Minnikin, D. E. (1979). Isoprenoid quinones in the classification of coryneform and related bacteria. J Gen Microbiol 110, 127-136.

Cui, X. L., Mao, P. H., Zeng, M., Li, W. J., Zhang, L. P., Xu, L. H. \& Jiang, C. L. (2001). Streptimonospora salina gen. nov., sp. nov., a new member of the family Nocardiopsaceae. Int J Syst Evol Microbiol 51, 357-363.

Evtushenko, L. I., Taran, V. V., Akimov, V. N., Kroppenstedt, R. M., Tiedje, J. M. \& Stackebrandt, E. (2000). Nocardiopsis tropica sp. nov., Nocardiopsis trehalosi sp. nov., nom. rev. and Nocardiopsis dassonvillei subsp. albirubida subsp. nov., comb. nov. Int J Syst Evol Microbiol 50, 73-81.

Gauze, G. F., Preobrazhenskaya, T. P., Sveshnikova, M. A., Terekova, L. P. \& Maksimova, T. (1983). Opredelitel'Aktinomycetov. Rody Streptomyces, Streptoverticillium, Chainia. Moscow: Izd. Nauka (in Russian).

Groth, I., Schumann, P., Weiss, N., Martin, K. \& Rainey, F. A. (1996). Agrococcus jenensis gen. nov., sp. nov., a new genus of actinomycetes with diaminobutyric acid in the cell wall. Int J Syst Bacteriol 46, 234239.

Grund, E. \& Kroppenstedt, R. M. (1990). Chemotaxonomy and numerical taxonomy of the genus Nocardiopsis Meyer 1976. Int J Syst Bacteriol 40, 5-11.

Hozzein, W. N., Li, W.-J., Ali, M. I. A., Hammouda, O., Mousa, A. S., Xu, L.-H. \& Jiang, C.-L. (2004). Nocardiopsis alkaliphila sp. nov., a novel alkaliphilic actinomycete isolated from desert soil in Egypt. Int J Syst Evol Microbiol 54, 247-252.

Jones, K. L. (1949). Fresh isolates of actinomycetes in which the presence of sporogenous aerial mycelia is a fluctuating characteristic. $J$ Bacteriol 57, 141-145.

Kämpfer, P. \& Kroppenstedt, R. M. (1996). Numerical analysis of fatty acid patterns of coryneform bacteria and related taxa. Can J Microbiol 42, 989-1005.

Kämpfer, P. \& Kroppenstedt, R. M. (2004). Pseudonocardia benzenivorans sp. nov. Int J Syst Evol Microbiol 54, 749-751.

Kämpfer, P., Steiof, M. \& Dott, W. (1991). Microbiological characterization of a fuel-oil contaminated site including numerical identification of heterotrophic water and soil bacteria. Microb Ecol 21, 227-251.

Kämpfer, P., Busse, H.-J. \& Rainey, F. A. (2002). Nocardiopsis compostus sp. nov., from the atmosphere of a composting facility. Int $J$ Syst Evol Microbiol 52, 621-627.

Kämpfer, P., Dreyer, U., Neef, A., Dott, W. \& Busse, H.-J. (2003). Chryseobacterium defluvii sp. nov., isolated from wastewater. Int J Syst Evol Microbiol 53, 93-97.

Kroppenstedt, R. M. \& Evtushenko, L. I. (2006). The family Nocardiopsaceae. In The Prokaryotes: A Handbook on the Biology of Bacteria, 3rd edn, vol. 3, pp. 754-795. Edited by M. Dworkin, S. Falkow, E. Rosenberg, K. H. Schleifer \& E. Stackebrandt. New York: Springer.

Kukolya, J., Nagy, I., Laday, M., Toth, E., Oravecz, O., Marialigeti, K. \& Hornok, L. (2002). Thermobifida cellulolytica sp. nov., a novel lignocellulose-decomposing actinomycete. Int J Syst Evol Microbiol 52, 1193-1199.

Lechevalier, M. P. (1968). Identification of aerobic actinomycetes of clinical importance. J Lab Clin Med 71, 934-944. 
Lechevalier, M. P. \& Lechevalier, H. A. (1970). Chemical composition as a criterion in the classification of aerobic actinomycetes. Int J Syst Bacteriol 20, 435-443.

Li, M.-G., Li, W.-J., Xu, P., Cui, X.-L., Xu, L.-H. \& Jiang, C.-L. (2003a). Nocardiopsis xinjiangensis sp. nov., a halophilic actinomycete isolated from a saline soil sample in China. Int J Syst Evol Microbiol 53, 317321.

Li, W.-J., Xu, P., Zhang, L.-P., Tang, S.-K., Cui, X.-L., Mao, P.-H., Xu, L.-H., Schumann, P., Stackebrandt, E. \& Jiang, C.-L. (2003b). Streptomonospora alba sp. nov., a novel halophilic actinomycete, and emended description of the genus Streptomonospora Cui et al. 2001. Int J Syst Evol Microbiol 53, 1421-1425.

Li, W.-J., Park, D.-J., Tang, S.-K., Wang, D., Lee, J.-C., Xu, L.-H., Kim, C.-J. \& Jiang, C.-L. (2004). Nocardiopsis salina sp. nov., a novel halophilic actinomycete isolated from saline soil in China. Int J Syst Evol Microbiol 54, 1805-1809.

Li, W.-J., Kroppenstedt, R. M., Wang, D., Tang, S.-K., Lee, J.-C., Park, D.-J., Kim, C.-J., Xu, L.-H. \& Jiang, C.-L. (2006). Five novel species of the genus Nocardiopsis isolated from hypersaline soils and emended description of Nocardiopsis salina Li et al. 2004. Int J Syst Evol Microbiol 56, 1089-1096.

Ludwig, W., Strunk, O., Westram, R., Richter, L., Meier, H., Yadhukumar, Buchner, A., Lai, T., Steppi, S. \& other authors (2004). ARB: a software environment for sequence data. Nucleic Acids Res 32, 1363-1371.

Meyer, J. (1976). Nocardiopsis, a new genus of the order Actinomycetales. Int J Syst Bacteriol 26, 487-493.

Minnikin, D. E., Alshamaony, L. \& Goodfellow, M. (1975). Differentiation of Mycobacterium, Nocardia, and related taxa by thin-layer chromatographic analysis of whole-organism methanolysates. J Gen Microbiol 88, 200-204.

Minnikin, D. E., Collins, M. D. \& Goodfellow, M. (1979). Fatty acid and polar lipid composition in the classification of Cellulomonas, Oerskovia and related taxa. J Appl Bacteriol 47, 87-95.

Olsen, G. J., Matsuda, H., Hagström, R. \& Overbeek, R. (1994). fastDNAml: a tool for construction of phylogenetic trees of DNA sequences using maximum likelihood. Comput Appl Biosci 10, 41-48.

Peltola, J. S. P., Andersson, M. A., Kämpfer, P., Auling, G., Kroppenstedt, R. M., Busse, H.-J., Salinoja-Salonen, M. S. \& Rainey, F. A. (2001). Isolation of toxigenic Nocardiopsis strains from indoor environments and description of two new Nocardiopsis species, N. exhalans sp. nov. and N. umidischolae sp. nov. Appl Environ Microbiol 67, 4293-4304.

Prauser, H. \& Falta, R. (1968). Phagensensibilität, ZellwandZusammensetzung und Taxonomie von Actinomyceten. $Z$ Allg Mikrobiol 8, 39-46 (in German).

Pruesse, E., Quast, C., Knittel, K., Fuchs, B. M., Ludwig, W., Peplies, J. \& Glöckner, F. O. (2007). SILVA: a comprehensive online resource for quality checked and aligned ribosomal RNA sequence data compatible with ARB. Nucleic Acids Res 35, 7188-7196.
Sabry, S. A., Ghanem, N. B., Abu-Ella, G. A., Schumann, P., Stackebrandt, E. \& Kroppenstedt, R. M. (2004). Nocardiopsis aegyptia sp. nov., isolated from marine sediment. Int J Syst Evol Microbiol 54, 453-456.

Schippers, A., Bosecker, K., Willscher, S., Spröer, C., Schumann, P. \& Kroppenstedt, R. M. (2002). Nocardiopsis metallicus sp. nov., a metal-leaching actinomycete isolated from an alkaline slag dump. Int J Syst Evol Microbiol 52, 2291-2295.

Schleifer, K. H. \& Kandler, O. (1972). Peptidoglycan types of bacterial cell walls and their taxonomic implications. Bacteriol Rev 36, 407-477.

Shirling, E. B. \& Gottlieb, D. (1966). Methods for characterization of Streptomyces species. Int J Syst Bacteriol 16, 313-340.

Tamura, K., Dudley, J., Nei, M. \& Kumar, S. (2007). MEGA4: molecular evolutionary genetics analysis (MEGA) software version 4.0. Mol Biol Evol 24, 1596-1599.

Tang, S.-K., Tian, X.-P., Zhi, X.-Y., Cai, M., Wu, J.-Y., Yang, L.-L., Xu, L.-H. \& Li, W.-J. (2008). Haloactinospora alba gen. nov., sp. nov., a halophilic filamentous actinomycete of the family Nocardiopsaceae. Int J Syst Evol Microbiol 58, 2075-2080.

Tian, X.-P., Tang, S.-K., Dong, J.-D., Zhang, Y.-Q., Xu, L.-H., Zhang, S. \& Li, W.-J. (2009). Marinactinospora thermotolerans gen. nov., sp. nov., a marine actinomycete isolated from a sediment in the northern South China sea. Int J Syst Evol Microbiol 59, 948-952.

Yang, R., Zhang, L.-P., Guo, L.-G., Shi, N., Lu, Z. \& Zhang, X. (2008a). Nocardiopsis valliformis sp. nov., an alkaliphilic actinomycete isolated from alkali lake soil in China. Int J Syst Evol Microbiol 58, 1542-1546.

Yang, L.-L., Tang, S.-K., Zhang, Y.-Q., Zhi, X.-Y., Wang, D., Xu, L.-H. \& Li, W.-J. (2008b). Thermobifida halotolerans sp. nov., isolated from a salt mine sample, and emended description of the genus Thermobifida. Int J Syst Evol Microbiol 58, 1821-1825.

Yassin, A. F., Galinski, E. A., Wohlfarth, A., Jahnke, K.-D., Schaal, K.-P. \& Trüper, H. G. (1993). A new actinomycete species, Nocardiopsis lucentensis sp. nov. Int J Syst Bacteriol 43, 266-271.

Yassin, A. F., Rainey, F. A., Burghardt, J., Gierth, D., Ungerechts, J., Lux, I., Seifert, P., Bal, C. \& Schaal, K.-P. (1997). Description of Nocardiopsis synnemataformans sp. nov., elevation of Nocardiopsis alba subsp. prasina to Nocardiopsis prasina comb. nov., and designation of Nocardiopsis antarctica and Nocardiopsis alborubida as later subjective synonyms of Nocardiopsis dassonvillei. Int J Syst Bacteriol 47, 983-988.

Yassin, A. F., Spröer, C., Hupfer, H., Siering, C. \& Klenk, H. P. (2009). Nocardiopsis potens sp. nov., isolated from household waste. Int J Syst Evol Microbiol 59, 2729-2733.

Zhang, Z., Wang, Y. \& Ruan, J. (1998). Reclassification of Thermomonospora and Microtetraspora. Int J Syst Bacteriol 48, 411422.

Zhang, X., Zhang, L.-P., Yang, R., Shi, N., Lu, Z., Chen, W.-X., Jiang, C.-L. \& Yu, L.-H. (2008). Nocardiopsis ganjiahuensis sp. nov., isolated from a soil from Ganjiahu, China. Int J Syst Evol Microbiol 58, 195199. 